\title{
Building the Infrastructure for the Observance of Refugee Rights in the Global South
}

\author{
BARBARA HARrEll-Bond
}

\section{Abstract}

Refugees in the Global South face many serious violations of their rights. Several major host states have failed to ratify both the Refugee Convention and the 1967 Protocol. However, even among those states that have ratified one or both, few have enacted the domestic legislation to implement the provisions, and no state in the South has made a serious effort to bring domestic law in other subjects-immigration, health, labour, education - into harmony with the rights of refugees and their international commitments.

This article presents a multi-faceted proposal, a guide to building a new global infrastructure for the protection of refugees. An important precursor is the rapid expansion in the teaching and studying of refugee law. Today's students of refugee issues are tomorrow's researchers, lawyers, and scholars, all of which are desperately needed to help refugees navigate the process of status determination and resettlement, to advocate more generally for the rights of refugees, and to monitor states' compliance with international obligations. Also, human rights NGOs need to embrace the fact that refugees are human beings, and refugee rights are human rights. Furthermore, advocacy groups, legal aid organizations, and other NGOs need to understand that advocacy, legal assistance, and research must go hand in hand: the provision of legal assistance to individual refugees not only makes the use of their life stories for research and advocacy more ethical, it improves the quality of the research and advocacy as well. Perhaps most importantly, all the groups working with refugees throughout the South must communicate with and assist each other.

In an effort to facilitate this crucial networking and communication, sixteen refugee advocacy and legal aid NGOs from the South attended a five-day workshop in Nairobi in January 2007. The group decided to form the Southern
Refugee Legal Aid Network, and to produce a charter for membership. I have been acting as the group's moderator informally since that time. In the coming months, SRLAN will attach itself to Fahamu, an advocacy NGO that publishes Africa's largest circulation magazine and has a proven track record of facilitating emerging advocacy networks. Fahamu will do fearless advocacy, often too dangerous for individual NGOs, and the SRLAN will facilitate the communication and co-operation necessary to begin the construction of the new global infrastructure for the protection of refugees. Working together, as a network of organizations throughout the South, we truly can transform this broken and unjust system.

\section{Resume}

Les réfugiés se trouvant dans le Sud global sont confrontés à de nombreuses violations graves de leurs droits. Plusieurs états hôtes importants refusent toujours de ratifier la Convention de 1951 et le Protocole de 1967. Cependant, même parmi les états qui ont ratifié l'un de ces instruments ou les deux, très peu ont adopté la législation interne qui permettrait de mettre en ouvre leurs dispositions, et pas un seul état du Sud n'a fait un réel effort afin d'harmoniser leur lois internes dans d'autres domaines - immigration, santé, travail, éducation - avec les droits des réfugiés et leurs propres engagements internationaux.

Cet article met de l'avant une proposition comportant plusieurs facettes - en quelque sorte un guide sur comment bâtir une nouvelle infrastructure globale pour la protection des réfugiés. Une importante condition de départ serait l'expansion rapide de l'enseignement et de l'étude du droit des réfugiés. Les étudiants d'aujourd'hui sont les chercheurs, les avocats et les universitaires de demain - tous des gens qui manquent désespérément pour aider les réfugiés à naviguer 
le processus de détermination du statut et de l'établissement, pour défendre et promouvoir plus généralement les droits des réfugiés, et pour surveiller de près le respect par les états de leurs obligations internationales.

De plus, les ONG s'occupant des droits de la personne doivent accepter le fait que les droits des réfugiés sont des droits de la personne. En outre, les groupes de revendications, les organisations d'aide juridique et d'autres ONG doivent réaliser que défense des droits, aide juridique et recherche doivent travailler de concert: lorsque l'aide juridique est fournie aux réfugiés à titre individuel, cela a pour effet non seulement de rendre plus conforme à léthique l'usage de leurs expériences pour la recherche et la promotion des droits, mais cela améliore la qualité de cette recherche et promotion des droits. Mais, le plus important peut être, c'est que tous le groupes travaillant avec les réfugiés à travers tout le Sud doivent communiquer entre eux et s'entraider.

Dans le but de faciliter l'émergence de ce réseautage et de cette communication, seize ONG du Sud, ceuvrant dans le domaine de la défense des droits des réfugiés et de l'aide juridique, ont participé pendant cinq jours à un atelier de travail qui s'est tenu à Nairobi au mois de janvier 2007. Le groupe a décidé de former le Southern Refugee Legal Aid Network ("Réseau du Sud d'aide juridique aux réfugiés »), et de préparer une charte pour les membres. Depuis lors, j’ai joué, de façon informelle, le rôle de modérateur du groupe. Dans les prochains mois, le SRLAN va se rattacher à Fahamu, une ONG de promotion et de défense des droits qui publie le magazine à plus fort tirage de tout l'Afrique et qui a de solides antécédents dans sa capacité de faciliter l'épanouissement de réseaux émergents de promotion et de défense des droits. Fahamu va organiser audacieusement la défense des droits, entreprise souvent trop dangereuse pour les ONG individuelles, tandis que le SRLAN va faciliter la coopération et la communication nécessaires pour commencer à construire la nouvelle infrastructure globale pour la protection des réfugiés. Travaillant de concert en tant que réseau d'organisations du Sud, nous pouvons transformer réellement ce système brisé et injuste.

\section{Introduction}

It is well known that the vast majority of refugees are hosted by the poorest countries in the world. Because of the restrictive policies of countries in Europe and North America, the grave reality is that most of them will stay in these countries, the so-called "Global South" (hereafter, South). Even if restrictions on movement to the North were relaxed, the ma- jority of refugees would remain in first countries of asylum because their numbers are so great.

Refugees in the South face serious violations of their rights and extreme levels of poverty. ${ }^{1}$ Moreover, large numbers of them are confined in camps and settlements where they are denied freedom of movement, which is fundamental to their ability to access all their other economic/social rights. ${ }^{2}$ Most spend decades "warehoused" in camps, where life is characterized by sub-nutritional diets, neglect of separated children, sexual and gender-based violence, threats, detention, beatings, torture, and even extrajudicial killings. ${ }^{3}$ Encamped refugees are also isolated from whatever protection might be accessed through the host state's judicial authorities. Disputes or infractions of rules within camps are managed by committees of fellow refugees who have assumed extrajudicial powers to administer corporal punishment, fine, and detain, acting completely outside the legal structure of the host government, often treating actions as "punishable crimes" that are not even included in a host state's criminal code, such as adultery. ${ }^{4}$

Although the right to identity papers is guaranteed under Article 27 of the Refugee Convention, refugees in camps are seldom issued anything other than a ration card issued to the head of the family. ${ }^{5}$ Even if a state (in concert with UNHCR) does issue a Convention Travel Document (CTD), few states are recognizing them. ${ }^{6}$

The injustice is not confined to camps. Host states in the South that allow refugees to live in urban areas usually deny them their rights to gainful employment, access to state schools, health services, and adequate housing. ${ }^{7}$

Article 8 of the 1950 Statute of the Office of the $U N H C R^{8}$ lists the protection responsibilities of this office. The statute does not go beyond requiring the office to promote the "conclusion and ratification of international conventions for the protection of refugees, supervising their application and proposing amendments thereto;"9 and to promote "through special agreements with Governments the execution of any measures calculated to improve the situation of refugees ..."10 The statute then lists activities, each of which presumes the existence of an effective and functioning judicial system and an active and independent civil society. While this may have been more or less the case in Europe at the time the Statute was devised, it is not the case in most countries of the South where so many refugees are hosted today. ${ }^{11}$

More than fifty years have passed since the promulgation of the Refugee Convention and the 1967 Protocol that expanded its scope to include the rest of the world, yet very little has been done to promote or protect the rights of refugees in the South. The available evidence suggests the situation for refugees in these countries is rapidly deteriorating. ${ }^{12}$ 


\section{The Infrastructure for Refugee Protection: What Is Missing?}

Over 145 states have ratified either the Refugee Convention or the 1967 Protocol, but several signatories-Madagascar, Monaco, Saint Kitts and Nevis, and Turkey-still do not accept any refugees from the South. Because they either have not become states parties to the 1967 Protocol, or have entered a reservation to the geographical expansion of the Protocol, they have only committed themselves to accepting refugees from Europe. Moreover, forty-five states have not ratified either the Refugee Convention or its Protocol, including such major hosting countries as Jordan, Syria, Lebanon, Indonesia, Malaysia, Nepal, Pakistan, and Thailand. ${ }^{13}$ How can we build a proper infrastructure for protecting refugee rights without this minimal legal foundation?

Among those States in the South that have ratified the Refugee Convention, very few have enacted domestic legislation to regulate the administration of that treaty or the other international human rights conventions that they have ratified. Where they have-in Tanzania, for example-there has been only one published account evaluating Tanzania's domestic law in terms of the degree to which it conforms to the standards of the Refugee Convention, ${ }^{14}$ and no court challenges have been made to its content. ${ }^{15}$ Even though Uganda's 2006 domestic legislation is very progressive in certain respects ${ }^{16}$ - for example, in that it includes gender-based claims for asylum ${ }^{17}$-it does not conform in other respects to the Refugee Convention, for example, by denying refugees the right to appeal against rejection.

In these situations, asylum seekers need lawyers to navigate the process and to challenge both existing refugee law and the implementation processes. In South Africa, for example, asylum seekers were given only seven days to appeal their rejections and were not given reasons for them. This grossly unreasonable refusal to provide reasons was only cured by the order granted by consent in the case of Pembele \& Others vs. Appeal Board for Refugees \& Others, ${ }^{18}$ a case brought by the Legal Resources Centre in Cape Town in 1996. ${ }^{19}$

Just as serious as the poor implementation of refugee law itself is the lack of effort to reform other domestic laws to bring them into harmony with refugee law. Extant and unreformed immigration, labour, health, and education legislation can be fatal to a refugee claim, especially if judges and defence lawyers are not trained in the relationship between domestic and international law as applied to refugees. Even in states such as Egypt, where the ratification of an international convention takes precedence over domestic law, that legal principle is unlikely to have any impact on asylum decisions if prosecutors and decision makers are not trained in the content and meaning of these conventions.
There are a host of other infrastructural problems that will need to be addressed if the rights of refugees are to be protected. The dearth of opportunities to seriously study refugee law at universities and law schools is a major problem all over the world. Even if a student specializes in public international law, the likelihood is that she or he will be made aware of the existence of the various refugee conventions in only one or two classes. But students need to study refugee law, in all its complexities. Without in-depth training in refugee law, they will not be prepared to practice it. ${ }^{20}$

In 1982, there were only two places in the world where refugee law was taught as a subject: Osgoode Hall Law School in Toronto, Canada, and the Refugee Studies Centre (RSC) at the University of Oxford. Today, there are more law schools that teach refugee law as an area of concentration, but they are still only a handful, and are concentrated mainly in the North. How many masters programs in human rights include refugee law as an area of specialization, much less teach it as one option? ${ }^{21}$

The lack of education has real consequences. Outside South Africa, ${ }^{22}$ there was no refugee legal aid NGO in the South before $1998 .^{23}$ Today, those lawyers who do practice in the South tend to be concentrated in the capital cities and are generally ill-equipped to deal with cases of violations of refugee rights. Judges and magistrates themselves are usually totally untrained in refugee law. ${ }^{24}$

Although human rights NGOs have multiplied in the South, it seems to have escaped the awareness of the human rights movement generally that a refugee is a human being with the same rights as the other people the movement focuses on. Little concern has been shown for refugee rights, ${ }^{25}$ and only a minuscule number of NGOs are providing legal assistance to them and advocating for their rights. ${ }^{26}$ This is reflected in the almost total neglect of violations of refugee rights by the Human Rights Council or the Office of the UN High Commissioner for Human Rights (OHCHR).

This office was created in 1993, and the HCHR is appointed by the UN Secretary General with the approval of the General Assembly. Perhaps its first mention of refugees came in 1997 by Mary Robinson, then-HCHR, in a speech entitled "Linkage between Human Rights and Refugees Issues." Some excerpts from this speech demonstrate her awareness of the connection between refugees and human rights, and her strong commitment to realizing the reciprocal benefits of cooperation between UNHCR and her office:

... Let me reiterate that human rights are indeed deeply connected to the problem of refugees. ... UNHCR and our Office are now looking at ways to strengthen and formalize this bilateral cooperation in a broad framework agreement, an MOU [Memorandum of Understanding], intended to deepen our 
cooperation not least through the holding of joint meetings and activities, through the exchange of staff, and co-sponsorship of staff training. ... [UNHCR], through its extensive field presence, could assist my Office, by signalling those situations requiring human rights operations, suggesting ways in which these operations could complement UNHCR's activities, and providing logistical support to the OHCHR field presence. ... In turn, in view of UNHCR's presence in a large number of countries, the sharing of information with rapporteurs and UN experts-however confidentially-may improve the quality and thoroughness of the work of the human rights machinery. ${ }^{27}$

One can only wonder why this offer of co-operation was not followed up, or why the HCHR continues, for the most part, to neglect the violations of refugee rights in host countries. Elizabeth Ferris acknowledges that:

[were] the Human Rights Council to establish a special working group, or special representative, to examine protracted refugee situations[, t]his would have the advantage of highlighting the constellation of human rights abuses which occur in protracted refugee situations and could be a way of pressuring governments to lift some of the restrictions on refugees.

But she argues that deference to UNHCR may undermine its independent human rights inquiries. For example:

The Working Group on Arbitrary Detention ... has not yet looked at restrictions on movement in protracted refugee situations.... [W] hen the Special Rapporteur [on torture] undertook a mission to Nepal (January 2006), he did not look into the situation of Bhutanese refugees ...

In fact, [the Office of the High Commissioner for Human Rights] defers to UNHCR in refugee settings. As pointed out in its training manual, 'it would not generally be the role of a UN human rights operation to visit a refugee camp managed by the UNHCR to review camp conditions. ... However, the mandate and expertise of UN human rights operations can often be complementary to an HCR role, provided there is adequate coordination.'

One of the obstacles to both OHCHR and [national human rights institutions] becoming more engaged in addressing the human rights of refugees in protracted refugee situations is the dominant role played by UNHCR in refugee camps. ... [I]t is hard for human rights organizations to decide to devote additional resources to human rights violations which are understood to be under the mandate of UNHCR. However, as we have seen, UNHCR has not been able to assure the human rights of refugees living in camps under its jurisdiction. Moreover, none of the human rights actors has done an adequate job in assuring the human rights of refugees in protracted refugee situations. ... [T] he dominance of UNHCR, particularly in camp settings, may have dissuaded human rights actors from closer scrutiny. ${ }^{28}$

The increase in the practice of adjudicating individual refugee claims in the South has created another gaping hole in the infrastructure that must be filled if refugees are going to succeed in having legitimate claims recognized. ${ }^{29}$ Formerly, refugees in the South, especially those who arrived en masse, were granted prima facie recognition and "gazetted" by the government (albeit as they were herded into camps). Today, however, it is becoming increasingly common for their status to be adjudicated individually, and in most countries of the South, this is being done by UNHCR. ${ }^{30}$

Unfortunately, the procedural standards applied by UNHCR country offices are far lower than those that the UNHCR declares that States should follow. ${ }^{31}$ UNHCR does not permit the refugee or the refugee's advocate access to the contents of the refugee's file or the transcript (let alone a tape recording) of his or her interview, and it withholds secret evidence from both the claimant and his or her representative. ${ }^{32}$ UNHCR also withholds country of origin information (COI), which may differ from that obtained by the legal advisor. If such evidence is incorrect, as it often appears to be, ${ }^{33}$ there is no way to refute it. UNHCR does not give reasons for rejections, rendering it almost impossible to mount an effective appeal. Moreover, "appeals" are reviewed by a colleague of the original decision maker; UNHCR does not provide for an independent appeal. ${ }^{34}$ Most UNHCR offices do not allow a legal representative to be present during the adjudication of a claim. Only in Egypt, ${ }^{35}$ Turkey, Lebanon, ${ }^{36}$ and most recently Kenya is representation allowed.

In 2006, UNHCR adjudicated claims for refugee status in eighty countries. ${ }^{37}$ This same year, it received 91,500 individual refugee applications, making it the largest refugee status decision maker in the world. Each application involves, on average, 2.4 family members. ${ }^{38}$ More than 79 per cent of these refugee status applications to UNHCR are made in countries that have ratified the Refugee Convention.

Since refugees are unlikely to be aware of refugee law (they are sometimes totally unaware the existence of UNHCR, to say nothing about its role in procedures in making their claims), it is crucial that refugees have access to legal aid and be represented as their claims are adjudicated. Research (19971999) in Uganda and Kenya, ${ }^{39}$ and in Egypt ${ }^{40}$ ascertained that refugees reported that legal aid was a priority need. ${ }^{41}$

Just as the staff of NGOs in the South need education and training in refugee rights and an understanding of the connection between human rights and refugee issues, so too are new NGOs needed, NGOs that will provide specialized and relentless legal representation to asylum seekers before 
UNHCR. These two infrastructural goals are inevitably connected: rights advocacy organizations can illuminate connections between human rights and refugee issues and identify cases in which targeted legal work is necessary and legal aid organizations can build cases that catalogue violations of refugee rights and create a factual record that allows for more effective advocacy.

\section{Making a Start}

In 2004, four refugee legal aid organizations began attending the September International Council of Voluntary Agencies (ICVA) and UNHCR's annual consultations in Geneva. Until $2008,{ }^{42}$ these meetings preceded the September meetings of UNHCR's Executive Committee and attracted the UNHCR's implementing partner NGOs, which are primarily concerned with delivering humanitarian assistance. 2004 marked the first time that NGOs working exclusively on issues related to the violations of refugee rights turned up at these consultations. Our reason for attending was to expose the whole NGO membership of ICVA to the procedural weaknesses of status determination as conducted by UNHCR. Side meetings and plenary sessions were designed to debate these issues. Each year these NGOs also arranged private consultations between the legal aid NGOs and staff of the Refugee Status Determination (RSD) unit within UNHCR, Geneva. ${ }^{43}$

The first positive result of such efforts was that UNHCR made public for the first time its "Procedural Standards for Refugee Status Determination under UNHCR's Mandate Status 2005." 44 Following the release, a group of NGO representatives and the UNHCR RSD Unit began an email discussion of the weakness of these "Procedural Standards." In the course of these discussions, UNHCR recommended that NGOs adopt a code of ethics for its staff if they hoped to be allowed to represent refugees in UNHCR's adjudications. ${ }^{45}$

UNHCR decided to write this code itself and its first draft included certain objectionable items, such as the requirement that the legal representative hand over all case notes to UNHCR, which would make the maintenance of attorney/ client confidentiality impossible. UNHCR also wanted to ensure that NGOs never represented an "unfounded" claim, with being struck off the list of approved organizations representing such refugees as the penalty if they did. Suffice it to say, the perception of a claim as "unfounded" is subjective, a matter of interpretation, ${ }^{46}$ and, ultimately, since the responsibility for giving accurate facts in the case rests with the claimant, NGOs could not tie themselves to such requirements. ${ }^{47}$ This "crisis" catalyzed the organization of a meeting for the purpose of devising a more workable code.

\section{Beginnings of a Southern Refugee Legal Aid Network}

In January 2007, a five-day workshop was convened in Nairobi. ${ }^{48}$ Sixteen refugee advocacy and legal aid NGOs from the South attended, ${ }^{49}$ two of whom represented networks with branches in a total of thirty-two African countries. Under the chairmanship of Michael Gallagher, a lawyer who works with the Jesuit Refugee Service in southern Africa, a committee was formed to write what has become the Nairobi Code. ${ }^{50}$

The group also decided to form the "Southern Refugee Legal Aid Network" (SRLAN) and went on to produce a charter for membership. Since that time, the network has been operating by email on an informal basis. I have been acting as its "moderator," linking members with my network of contacts and working to expand it. During the year and a half the group has existed, members have been sent information on UNHCR's changing policies and have exchanged and responded to urgent calls for information concerning cases. Refugees have been assisted. Just one example: a Tanzanian was refouled from Australia to Tanzania but immediately escaped to Zambia. I got word of this and the next day he was in contact with two NGOs in Zambia. NGOs have supported each other with such diverse tasks as reuniting children across borders and finding competent refugee translators for preparing information pamphlets in different languages. They have also responded to unique requests for $\mathrm{COI}$ that are not covered in RefWorld, UNHCR's source of COI.

The SRLAN has held two meetings in Geneva, in September 2007 and June 2008, which were also attended by representatives of UNHCR's RSD Unit. At its second meeting the SRLAN shared experiences of the operations of the network since its inception, planned its website pages, and reviewed the use of the Nairobi Code. The group approved its vision and mission statement, ${ }^{51}$ and set an ambitious work program for itself for the first year: defining a membership strategy, revisiting the Nairobi Code, establishing secure communication systems, developing a plan for training, and creating a COI database that goes beyond UNHCR's RefWorld and other traditional sources of information to meet the needs of the network. ${ }^{52}$ This will include a list of academic countryof-origin specialists who are prepared to provide pro bono affidavits for particular cases.

The SRLAN will attach itself to Fahamu, an NGO with offices in Kenya, Senegal, South Africa, and Oxford..$^{53}$ Fahamu's advocacy work aims to support human rights and social justice movements by promoting the innovative use of information and communications technologies to stimulate debate, discussion and analysis. ${ }^{54}$ Fahamu has a proven track record in facilitating the emergence of advocacy networks. ${ }^{55}$ While 
concentrating on Africa, Fahamu has experience with global networks and will facilitate SRLAN's international reach.

Fahamu publishes the newsletter Pambazuka News, produced by a pan-African network of around 500 citizens and organizations, and with a readership of around 500,000 people, it is now Africa's largest circulation magazine and online platform dedicated to human rights and social justice in Africa. It publishes articles on a wide range of subjectsto date over 2,000 on refugees and forced migration-and, in collaboration with SRLAN, it will strengthen its coverage of refugee rights internationally. It is published in English, French, and Portuguese, soon to expand to Arabic.

Fahamu's portfolio of distance learning courses has also been widely praised. ${ }^{56}$ Some 1,000 organizations and participants have completed its courses since 2003, and the methodology has been adopted by other institutions such as the University of Oxford and the office of the UNCHR.

The advantages of attaching the SRLAN to Fahamu are several, but the most salient for network members is Fahamu's freedom to do fearless advocacy. It is not enough to pass crucial protection information to Amnesty, Human Rights Watch (HRW), or the US Committee for Refugees and Immigrants (USCRI); if publicity and the shaming of governments are to have any impact or effect, they must be done rapidly. However, being identified with any public advocacy on particular issues and cases can be dangerous for individual NGOs. ${ }^{57}$ Fahamu, through its weekly newsletter, is able to do such advocacy while keeping sources anonymous. ${ }^{58}$

Through SRLAN and Fahamu, legal aid organizations will have the array of sources they need to obtain accurate information, as well as the extensive contacts they will need to initiate public advocacy when the litigation of one case identifies broader systematic problems. And advocacy groups will have access to the education they need to understand the complexities of refugee rights, as well as the contacts they need to identify the most immediate threats to those rights.

\section{The Challenges Ahead}

\section{Advocacy}

The most serious and immediate problem facing refugees is the violation of their rights, beginning with the dangers of $r e$ foulement. UNHCR's role in the "protection" of refugee rights is ambiguous to say the least. Since it relies on "quiet" diplomacy with governments, it is not possible to know empirically whether it is actually preventing worse violations than would occur without it. ${ }^{59}$ Even at its Executive Committee (ExCom) meetings, UNHCR is apparently hesitant to "name and shame" particular governments. In a speech to ExCom by Erika Feller, the Assistant High Commissioner for Protection, she noted that " ... 30 per cent of all refugee children are not regularly attending school; that military recruitment of children occurred in some 6 per cent of refugee camps; that fewer than 50 per cent of refugees in 82 countries surveyed enjoyed full freedom of movement and the right to work ..."60 Such statistical compilations of violations would imply that UNHCR is "monitoring" states' performance, but the real effect of such generalized and anonymous reporting is dubious.

In the crisis that began in 2007 in the Aswan region of Egypt, some 1,500 Eritrean and others nationalities who were ostensibly seeking to smuggle themselves to Israel were detained in inhumane conditions. Several Egyptian NGOs, Amnesty International, and the Euro-Mediterranean Human Right Group's subcommittee on migrants and refugees (MAWG) ${ }^{61}$ mounted a concerted international campaign attempting to force the Egyptian government to allow UNHCR access. It was only after High Commissioner for Human Rights Louise Arbour issued a press release decrying the situation that Egypt finally agreed. ${ }^{62}$ Before UNHCR was allowed access to the refugees, however, Egypt had already refouled at least 700 Eritrean asylum seekers. ${ }^{63}$

It is significant that neither AMERA Egypt (which provides legal aid to refugees), nor its UK parent organization, AMERA UK (which raises funds for AMERA Egypt) publicly joined this campaign. Like most foreign human rights NGOs in Egypt, AMERA Egypt is allowed to operate under the Ministry of Foreign Affairs, but since it registered in late 2003 , it has never been given a registration number. The insecurity among AMERA's Egyptian staff (and its UK board members) seems to encourage unnecessary self-censorship. It is difficult to ascertain whether their fear of being closed down if they engage in such advocacy is justified. ${ }^{64}$

Most refugee NGOs limit their work to advocacy and policy work rather than providing legal services. ${ }^{65}$ It is difficult to conceive how one does effective advocacy/policy work without in-depth research, which requires interviewing individual refugees. However, interviewing individual refugees for advocacy/policy work without then providing legal aid, when it is apparent that it is necessary, raises ethical questions. When researching for Rights in Exile, ${ }^{66}$ we found that we could not say to a refugee who has just divulged their situation (which will likely involve terrible suffering if not torture and/or despair about their current state of affairs), "Thank you very much for the information you have provided, it will help my research." We found it was absolutely necessary on ethical grounds to offer legal aid with such individual interviews. ${ }^{67}$

This is not to suggest that advocacy and policy work per se should stop, simply that it should be embedded in the refugee experience and all our experience indicates that the best advocacy is an outgrowth of providing legal aid. The lack of ma- 
terial assistance is real in most situations, although this could be overcome by refugees themselves if they were enjoying their rights. Thus it is necessary not only to connect advocacy groups to legal aid networks through an umbrella network like SRLAN, but to encourage, and train, advocacy organization to provide some legal assistance themselves. Not only is this advocacy more ethical in what it asks of and provides for individual refugees, it will also be better informed and more effective than "pure" research. Only this kind of advocacy can turn the tide of the realization of refugee rights.

\section{Developing a Strategy to Convince Governments to Ratify the Convention, Introduce Domestic Refugee Legislation, and Reform Other Legislation to Conform}

To succeed in the aim of convincing non-signatory countries to ratify the Convention as well as to introduce domestic legislation to regulate the implementation and reform other legislation in conformity with it will require concerted efforts on the part of actors both inside and outside the country. Lessons can be drawn from Fox and Brown's The Struggle for Accountability: The World Bank, NGOs and Grassroots Movements. ${ }^{68}$

This book is a theoretical analysis of what it took to hold the World Bank to account for violations of the rights of various peoples whose lives and livelihoods were being destroyed by "development projects." In summary, it shows that it was only when "grassroots movements" protested in dramatic ways and Northern NGOs supported their work through lobbying government members of the World Bank that any progress was made. Fox and Brown are very careful to explain the complexity of the situation and to argue that success was the result of numerous variables; one cannot identify precisely what factors brought about the change. Nonetheless, their study demonstrates new understandings of the effective roles of insider/outsider and how their collaborations can result in positive advocacy.

In order to encourage the ratification of the Convention, and introduce domestic refugee law and law reform, it will be necessary to engage representatives of parliaments, political parties, ExCom governments, donors, legal specialists, and others. Together, they will need to devise an effective local strategy in each country concerned and to identify a strong NGO to lead this process on a country by country basis.

\section{Convincing Law Schools to Offer Refugee Law Courses}

It has probably been almost accidental that law schools began offering courses in refugee law. It is rare that law schools go beyond simply mentioning the Refugee Convention in a public international law course. No concerted effort has been made to convince law faculties either of the "market" for such courses or of their possible impact, especially if they were combined with the legal aid clinics that provide students with practical experience. Readers will doubtless have ideas of many "entry" points to begin such a campaign. Do we need to form a syndicate of refugee law professors, analogous to that of International Association of Refugee Law Judges (IARLJ), ${ }^{69}$ to take over this responsibility?

There is great need to increase legal scholarship in and on the South, scholarship that could provide the grounds for lobbying/campaigning as well as court work. There are scores of law students who could be challenged to focus their masters, J.D., and/or doctoral research on refugee issues. Suggestions include such exercises as an analysis of domestic refugee law, where it exists, as well as other domestic law, in terms of its conformity with refugee law (see above). Statelessness, an issue that is also the responsibility of UNHCR, has also received too little academic attention, among other pressing concerns.

If law schools were to begin offering robust education in refugee law, it is not only legal scholarship that would benefit. As discussed above, a new generation of refugee lawyers is needed to monitor compliance with and implementation of international commitments, to explore the connections between human rights and refugee issues, and to provide legal aid to individual asylum seekers trying to navigate the UNHCR or state process.

\section{Increasing Training in Refugee Law Worldwide}

Several years ago, UNHCR, through the Hungarian Helsinki Committee, began a program to start legal aid clinics in the states in Central and Eastern Europe which were aspiring to join the European Union. As a result of this investment, we now have a resource for law teachers, whether or not they are versed in refugee law, to introduce the subject. Created by groups of refugee law specialists, it is an online "living casebook," the Refugee Law Reader (the Reader). ${ }^{70}$

While it was initially developed to provide legal resources and guidance for young professors in the region of East and Central Europe, it is now being used on five continents, by both experienced and new professors, advocates and researchers. The next edition will launch the French, Spanish, and Russian versions of the Reader, as well as expand its scope to include new sections on Africa, Asia, and Latin America.

The Reader contains a comprehensive adaptable curriculum that is designed for teaching across different legal systems, but one of the notable benefits of being a "living casebook" is that it is able to keep pace with an area of law that is in a period of rapid development. The Reader also provides the complete texts of over 600 up-to-date core legal materials, instruments, and academic commentary.

The Refugee Law Reader is designed primarily for refugee law instructors, although NGOs that practice legal aid 
can have access to many of the documents. In the meantime, there is a need for a distance learning course for the great number of countries where there is no access to such formal teaching. Fahamu will be developing one.

We have already mentioned the urgent need for training on refugee rights among the hordes of actors whose professional lives put them into daily contact with refugees, such as the police, immigration officers, camp managers, teachers, religious leaders, NGOs that serve (or fail to adequately serve) these populations, and refugees themselves. I only know of one organization, the Refugee Law Project in Uganda, that has a year-round program of such training. ${ }^{71}$

But there are encouraging signs. The International Associations of Refugee Law Judges has held training conferences in Uganda, Egypt, Ethiopia, Ukraine, Russia, Belarus, Georgia, Malta, Poland, Japan, the Philippines, Ireland, Slovakia, Hungary, the Czech Republic, and Slovenia. Judges from many of the Eastern European countries which were applying to join the EU were also gathered in various places at various times in other centres. Judges from all over the world have attended training sessions at conferences organized by the IARLJ in New Zealand, Canada, Ireland, the UK, Switzerland, and Sweden. The next world conference is in Cape Town, South Africa, in January 2009. ${ }^{72}$ It is intended that the SRLAN and the IARLJ will develop closer links to bring such training to more countries in the South.

\section{Building Capacity to Provide Legal Aid in the South}

Although important, advocacy condemning the violations of rights after they have occurred is not enough. The major challenge facing the network will be to strengthen the capacity of existing refugee NGOs or to help new ones emerge, in order to provide legal assistance to individual refugees. The network's ultimate goal would be to have a least one such NGO devoted to this work in every country in the South. The task is enormous, but a promising start has been made.

AMERA $\mathrm{UK}^{73}$ is funding AMERA Egypt and partially funding the Refugee Law Project in Uganda. ${ }^{74}$ The Dutch foundation 3Rs Stifting is also raising funding for legal aid in the South. ${ }^{75}$ Operating on a financial shoestring, Asylum Access $^{76}$ has started new legal aid NGOs in Ecuador and Thailand. It has plans to found another in Tanzania in 2009.

In 2008, I was able to send Christophe Chabaud, a French lawyer who was a former student of mine at the American University in Cairo, to Senegal. There, he worked for nine months with the office of the West African Refugees and Internally Displaced Persons (WARIP) Network. ${ }^{77}$ Lisa Weinberg, an experienced refugee lawyer, also spent a month there writing a critical overview of the refugee situation in Senegal. ${ }^{78}$ Although this WARIP Network office is experienced in refugee advocacy, and has even taken cases to the
African Commission on Human and People's Rights, it had little experience preparing testimonies for first instance applications to the Senegalese government or for appeals against rejection.

Alice Nah, who is organizing an Asia Pacific Regional Consultation on Refugee Rights on behalf of the Asian Forum for Human Rights and Development (Forum Asia), a regional NGO based in Bangkok, is planning to hold a first meeting in November 2008 in Malaysia. Thus far, this network is concerned with building collaboration across the Asia Pacific region and enhancing advocacy on behalf of refugees. Hopefully some of these NGOs will develop the skills to represent refugees with all aspects of their legal needs.

Another important role for these NGOs will be to monitor the work of UNHCR for irregularities in its procedures wherever it does refugee status determination. UNHCR cannot expect states to do better than it does, so it must set the highest example. The Helsinki Citizens' Assembly-Turkey's Refugee Advocacy and Support Program has integrated monitoring of UNHCR's practices into its mandate. ${ }^{79} \mathrm{My}$ experience in the past has been that states in the South usually have a higher acceptance rate than UNHCR. For example, in the 1990s, Tanzania was accepting 98 per cent of individual claims, a fact that the UNHCR office in Tanzania complained about. ${ }^{80}$ On the other hand, generally UNHCR's rate of acceptance is much higher than of the same populations in European and North American countries. For example, UNHCR in Turkey recognizes 75 per cent while its neighbour, Greece, a member of the European Community, recognizes less than 1 per cent.

\section{Conclusion: "Simply Irritated at Injustice"}

However enthusiastic the members of the SRLAN itself, it is an understatement to say that promoting respect for refugee rights in the Global South will require the concerted efforts of individuals and institutions from around the world. I believe that all who read Refuge are as concerned as I am at the extent to which the very institution of asylum is under serious threat. ${ }^{81}$ Many of us are extremely troubled about the expansion of UNHCR's mandate to include internally displaced persons (IDPs). UNHCR was never intended to become the world's largest welfare agency for displaced people: it was established to protect the rights of refugees.

The protection of those rights necessitates an international effort to build a new infrastructure in the South. Students must learn refugee law and human rights and must be encouraged to undertake research in numerous ill-explored topics. Better training in refugee rights, refugee law, and the interaction between domestic and international commitments must be offered to all the actors in the system. A new generation of better-educated and better-trained researchers, 
lawyers, and scholars must carefully monitor implementation of and compliance with international commitments. Legal aid organizations must engage not only in the representation of individual clients and careful monitoring of domestic and international law, but also in fearless advocacy for refugee rights more generally. Advocacy organizations must see the benefit of providing legal assistance, both for individual refugees and for the quality of the advocacy itself. And the various actors in the field, doing research, monitoring, legal aid, and advocacy, must communicate with and assist each other. Most of all, what is needed is vision, determination, and persistence. A new infrastructure is possible.

I think it best to conclude this paper anecdotally, with the story of how one person, Pamela Baker, a barrister from the UK, worked to change the situation for Vietnamese in Hong Kong, and how her efforts have had a lasting impact there and elsewhere for these refugees. She is the first person I know who responded to the need for refugee legal aid in the far corners of the world, and who inspired young volunteers to join her in this work. She was working for the Hong Kong Legal Aid Department, ${ }^{82}$ when, in 1990, the territory changed its policy vis-à-vis the Vietnamese, introducing a screening process designed to send them back to Vietnam.

Baker broke with her department's policy, granted legal aid to the entire crew and passengers of a boat so that they could bring habeas corpus applications to challenge their detention. The case became known as Boat 101 and caused considerable embarrassment to officials from Hong Kong to Whitehall. ${ }^{83}$ UNHCR accused Baker of fostering false hopes among the boat people, and consequently government officials banned her from the camps and her files were removed. ${ }^{84}$

She resigned and set up law offices in her home, inviting young lawyers to work with her as volunteers. One, Mark Daly, describes the early days:

At any one time there were about 6 lawyers-including Peter Barnes from Australia, myself from Canada, 2 lawyers from the UK, another from Australia and one from the US. A law professor, a volunteer, acted as clerk. Most of the work was done pro bono-with some battles to get the Legal Aid Department to back up a case to keep the firm going. I know that Peter taught piano lessons to supplement his stipend and I taught tennis lessons. Vietnamese refugees would sometimes reward us with mangoes or the occasional bottle of brandy.

Hoi Trinh, a Vietnamese volunteer lawyer from Australia, writes:

With a team of young volunteer lawyers and wannabes, [myself] included, Pam set out to launch a series of landmark cases against cruel bureaucratic decisions made by first, the Hong
Kong, then the British, and later, the Chinese administrations. To many a refugee, she was a savior. But I remember she used to respond to such acclamation with classic English understatement: "I am simply irritated at the injustice." And as justice every so often demands, Pam's fights resulted in thousands of releases and changed many refugees' lives forever. To this day, I suspect, across the globe, her name still resonates in Vietnamese homes with much respect and admiration. As for me, apart from showing me how to be a true lawyer at a time when I was trying to imitate one, Pam showed me how to be genuinely caring of one's clients, to really listen without prejudice, that in the end one should "just do it and life will take care of the rest", and perhaps most importantly, that one should only really work if it's fun. "The moment you stop having fun, it means your heart is no longer there. Move on," she used to say. For all that I must thank her. Had I not met her, I wouldn't have had the courage to call it quits at the corporate law firm I was working for in Australia. Had I not met her, I wouldn't have found my calling in the Philippines. ... ${ }^{85}$

When Pam Baker became ill with cancer, Mark Daly and Peter Barnes established the law firm Barnes \& Daly in Hong Kong. They won a case in the Court of Final Appeal, ${ }^{86}$ where it was determined that a refugee who had been rejected by UNHCR could not be refouled because of the threat of torture. ${ }^{87}$

By way of short update, our firm continues to advise hundreds of asylum-seekers-and since the Court of Final Appeal case of Prabakar-CAT applicants. ... we continue to take cases challenging a number of the government policies with respect to asylum seekers in the areas of detention, support and social assistance, prosecution policy, fairness of the RSD procedures and the CAT process, as well as making individual submissions to the UNHCR despite the lack of procedural fairness in that process. In addition, we take constitutional challenges in general human rights in an attempt to make the courts more receptive to international human rights law. ${ }^{88}$

Recently, two other unsung heroes, Adam Shapiro ${ }^{89}$ and Perla Issa, have taken up the torch to evacuate the Iraqi Palestinians stranded in camps on the Syrian-Iraqi border and inside Jordan They approached non-traditional resettlement countries where there were already large settled Palestinian and other Arab communities as well as places like South Africa, Malaysia, and New Zealand. They went to Chile, having made contact with a senator there who set up meetings with politicians, government officials, human rights and community leaders, and businessmen in Santiago. Having gotten the issue at the top of the agenda with these groups, including the Deputy Secretary of Interior, in April 
2006, the Chilean Ambassador formally declared Chile's intention of taking 110 refugees. A misinformation campaign began in Chile that almost scuppered the scheme. Adam Shapiro returned in August 2007 and a firm decision was taken by the government to accept 117 from Al-Tanf Camp in the no-man's-land between Syria and Iraq. At writing, news has just been received that the first baby born to one of these Palestinian refugees since arrival in Chile has been delivered, named Rafi. His mother was overjoyed, telling wellwishers she was "very emotional that her son will be born a Chilean."

Similar negotiations were undertaken with Brazil, which resulted in its willingness to take Palestinians from Runwayshid camp, located just inside Jordan, near the border with Iraq. In September 2007, the first group of 35 Palestinians left for Brazil (out of a total of 127). In Brazil, UNHCR and NGOs have taken the responsibility for integration, language training, and other services for the newly arrived refugees.

Adam Shapiro and Perla Issa have also gone to Caracas, Venezuela, and are following up with the President's office and the Ministry of Foreign Affairs there. They have begun to make contacts in South Africa, Spain, Costa Rica, Malaysia, Australia, and New Zealand and are planning similar efforts with Uruguay and Ecuador.

Yemen was approached to provide a temporary place for all the Palestinian refugees from Iraq living on the borders as well as in Baghdad, but this idea for temporary respite from the desert camps while they worked to get the entire group resettled was undermined by less-than-determined efforts by the UNHCR and the PLO, as well as a seeming lack of motivation to address the urgency of the situation. In the camps on the border as well as in Baghdad, Palestinians face targeted attacks, killings, and kidnappings, and other violence persists, specifically against Palestinians.

Sudan's offer to resettle the refugees was rejected by a vote in the Al-Walid and Al-Tanf camps when it was first announced. However, the PLO has pressed forward with the initiative and, given lack of options, or even hope for options, some refugees are considering accepting Sudan. However, now that the International Criminal Court (ICC) has taken measures against the government, it is to be determined if the UNHCR as an agent of the international community will press forward.

It is a long and slow process depending on the diplomatic skills and personal financial resources of just two individuals, something akin to the work of Hoi Trinh, the Vietnamese lawyer in the Philippines.

\section{Appendix}

\section{The Nairobi Code}

\section{MODEL RULES OF ETHICS IN REFUGEE CASES}

1. SCOPE AND PURPOSE

These rules are intended to guide legal aid providers in the context of refugee status determination procedures and other legal aid services offered to refugees.

These rules are subordinate to any applicable domestic rules governing the provision of legal services, and are intended only to supplement such rules.

\section{DEFINITIONS}

The term "legal advisor" refers to any person providing advice and/or representation to people seeking recognition as refugees, or to people who have been recognized as refugees and are seeking other assistance.

The term "services" refer to the advice, document preparation, and/or representation that a legal adviser may provide.

"Advice" includes providing an opinion about how law or policy applies to a particular person's circumstances.

"Document preparation" includes assisting a person in preparing written documents in the person's own name, including but not limited to personal testimonies, that are intended for submission in support of an RSD or other application.

"Representation" includes acting on behalf of another person either orally or in writing, including the submission of memoranda arguing that a person meets the legal criteria for refugee status or communicating with UNHCR or other bodies on a client's behalf about his or her case.

The term "client" refers to a person to whom a legal adviser has agreed to provide services and who voluntarily accepts those services.

The term "prospective client" refers to a person who has sought services from a legal adviser but to whom the adviser has not yet agreed to provide services.

\section{ADVISOR-CLIENT RELATIONSHIPS}

3.1 Advisors shall in all cases clearly explain to prospective clients whether they can offer services of any kind, and shall provide clear explanations of the type of services they offer. The objectives and scope of any advisorclient relationship shall be explicit before the advisor begins to conduct any work on the case, and before the client is asked to agree to the representation.

3.2 In order to maximize impact, legal aid providers may limit their services. For instance, some agencies may provide only advice or document preparation, or may focus their services on particular types of client who either have particularly acute needs or whose cases raise especially important legal issues. However, advisors must inform clients of any limits in the services 
to be provided at the beginning of the advisor-client relationship.

3.3 Notwithstanding Rule 3.4, a legal adviser is under no obligation to provide services to a prospective client, and may decide to decline to provide assistance unless prohibited by Rule 3.4 .

3.4 Subject to the provisions of rule 3.2, legal advisers shall not deny services to any person on the basis or race, gender, sexual orientation, nationality, political opinion, religion, age, family status, indigence or membership in a particular social group.

3.5 Advisor-client relationships may begin only with the voluntary, informed consent of the client, and may continue only if this consent continues. A client may end his or her relationship with a legal adviser by clear and explicit communication, orally or in writing. An allegation by a client of ethical misconduct against an advisor shall be presumed to indicate that the client no longer consents to continuing the advisor-client relationship.

3.6 Clients should remain in control of the goals of representation. If at some point during the advisor and client relationship, the client and advisor are unable to agree on the goals or strategies of representation the advisor may withdraw from representation.

3.7 Clients shall be entitled to view and obtain copies of all materials in their files. Legal advisers shall provide copies of the materials to the client upon the client's request, during or after the end of the advisor-client relationship. However, advisers may maintain records of their work on a client's case, and are not required to destroy files, even if requested by a client.

3.8 The legal adviser shall notify the adjudicating body in writing when the advisor client relationship has terminated.

4. DILIGENCE

4.1 An advisor shall act responsibly and with due diligence in the handling of a client's case and shall act within the bounds of the law and these rules to obtain the best results possible for the client.

4.2 Advisors shall complete all work as agreed with clients. Advisors shall complete all required documents for a client by any deadline applicable.

4.3 Advisors are responsible for maintaining regular access to published UNHCR materials and country of origin information necessary to assist clients in refugee status determination applications and other matters.

4.4 Advisors shall maintain a filing and records system in order to record their work on a client's case.

\section{CONFLICTS OF INTEREST}

5.1 Advisors shall not provide services to any prospective client where the advisor has a direct financial or personal interest that is opposed to the client's interest.

5.2 Advisors shall not offer services to any prospective client where another client of the same advisor has interests that are opposed to the prospective client's interests.

5.3 Where two clients of the same advisor develop a conflict of interests after the beginning of an advisor-client relationship, and where local ethical or professional standards would permit, the advisor shall seek to refer one or both of them to alternative advisors immediately.

5.4 Where advisors have a personal relationship with the client that could interfere with his or her exercising objective judgment, the advisor shall seek to refer the client to an alternative legal advisor, if available.

5.5 Where Rule 5.3 or 5.4 applies and alternative legal advisors are unavailable, an advisor may assist clients where a conflict of interest exists only after clearly and explicitly notifying the clients of the conflict and its potential consequences, and after seeking ways to limit the scope of representation so as to minimize conflicts.

\section{CONFIDENTIALITY}

6.1 Clients and prospective clients are entitled to confidentiality of the information obtained from them or others by their advisors. The confidentiality privilege is owned by the client, not by the advisor. Except as provided for in these rules, confidentiality may be waived only with a client's explicit consent.

6.2 An advisor shall protect the confidentiality of all information that is gathered regarding a client's affairs, except as specifically provided for in these rules. Advisors shall maintain files and records in a manner designed to protect the clients' confidentiality. The duty to maintain client confidence continues beyond the termination of the advisor client relationship unless otherwise provided in these rules.

6.3 Confidentiality shall not apply to information that has entered the public domain with the client's consent. When a client voluntarily allows a piece of information to enter the public domain, the client will be presumed to have waived confidentiality on that piece of information. However, advisors may not reveal information that has entered the public domain against the wishes of the client, or without the client's consent.

6.4 An advisor may reveal confidential information about a client to other legal advisors for the purpose of professional consultations, so long as the other advisors 
will be bound by the same duty of confidentiality and so long as the other advisors do not have a conflict of interest as described in Rule 5.

6.5 Where an advisor believes a client is likely to inflict bodily harm on another person in the imminent future, the advisor must take prompt steps to inform the appropriate authorities, and may reveal that amount of confidential client information which is necessary to prevent bodily injury.

6.6 An advisor may reveal confidential information as minimally necessary to defend him or her from any formal accusation of breach of these ethical rules.

6.7 A legal advisor or organization employing a legal advisor may use information collected from clients' cases in publication and writings without the consent of affected clients only if the publication is sanitized of any unique details that would allow an interested person to identify the person involved.

6.8 A legal advisor or an organization providing legal services must train all staff and support personnel on their responsibility to maintain client confidential information and ensure that client confidences are maintained.

\section{DUTY OF INTEGRITY}

7.1 An advisor shall adhere to the truth in all communications, shall urge his or her clients to do the same, and shall not encourage, advise, or assist any person to make false or misleading statements to any tribunal or agency before whom the advisor appears on the client's behalf.

7.2 Notwithstanding Rule 7.1, the advisor is not the decision-making body regarding the validity of applications for refugee status recognition or other matters, and has no duty to screen out or turn away prospective clients who have relatively weak claims.

7.3 An advisor shall conduct his or her interactions with other parties in a courteous, professional manner, consistent with principles of respect for other people and principles of human rights and non-discrimination.

7.4 When an advisor knows that a client has made misstatements of fact to a tribunal or adjudicating body before the beginning of the advisor-client relationship, and there are no contrary local profession ethical rules, the following shall apply:

7.4.1 The advisor shall not reveal the past misstatements to any person or body without the client's explicit consent.

7.4.2 The advisor shall attempt to persuade the client to correct the statements.

7.4.3 The advisor shall not proceed in making any communication to the adjudicating body or any other body that are founded on the past misstatements, and shall not take any actions likely to lead the adjudicating body or any other body to rely on the past misstatements.

7.5 An advisor shall not knowingly sign or otherwise be associated with any letter, report or other documents, make any statement or offer any submission with respect to a client which contains false or misleading information. An advisor shall not submit to an adjudicating body any document which the advisor knows to either be a forgery or to contain false or misleading information.

7.6 When client makes statements to an adjudicating body after the beginning of the advisor-client relationship that the advisor knows to be false, the following shall apply:

7.6.1 The advisor shall not reveal the misstatements to any person or body without the client's explicit consent.

7.6.2 The advisor shall attempt to persuade the client to correct the statements to the adjudicating body.

7.6.3 The advisor shall not proceed in making any communications to the adjudicating body or any other body that are founded on the misstatements, and shall not take any actions likely to lead the adjudicating body or any other body to reply on the misstatements.

7.6.4 Where the misstatement goes to the heart of the representation and the client refuses to correct the misstatement, the legal advisor shall cease the representation.

\section{DUTY TO AVOID EXPLOITATION}

8.1 An advisor shall not engage in any relationship either directly or indirectly that is likely to compromise his or her independent judgment on behalf of the client in rendering legal services and shall not exploit his or her client for financial, sexual or other gain. To avoid all doubt, any sexual or business relationship between a legal advisor and a current client shall be presumed to be exploitative.

8.2 Advisors shall not solicit or receive any services, products, or labor for which a person might normally be compensated in money or other exchange from any current client or for six months after the end of an advisor-client relationship, except as permitted by Rule 5.5 where a relationship pre-existed the need for legal services and no alternative legal advisors are available.

8.3 Advisors shall not enter into any financial relationship with any current client or for six months after the end of an advisor-client relationship. 
Promulgated at

SOUTHERN REFUGEE LEGAL AID CONFERENCE

(SRLAC)

Nairobi, Kenya

1 February 2007

\section{Attached Annexes}

- Annex 1 Model Minimum standards of qualifications for Legal Advisors for Refugees

- Annex 2 Complaint Mechanism as a Feature in a Professional Accountability Structure for Legal Aid Providers

\section{Annex 1}

MODEL MINIMUM STANDARDS OF QUALIFICATIONS FOR LEGAL ADVISORS FOR REFUGEES

Qualifications of Legal Adviser: Subject to any domestic rules to the contrary, a person may be recognized as a legal advisor for refugees if they meet either criteria A or B:

Criteria A:

- Current license issued by the relevant authority of a member state of the United Nations as a lawyer, solicitor, attorney, barrister, counselor-at-law or equivalent professional designation.

Criteria B:

- Undergraduate degree, equivalent to a Bachelor's degree or

- $\quad$ is a current student in a supervised legal clinic connected with an accredited university or other legal institution or

- Is a person with more than 2 years experience working in refugee matters

and

- Training in refugee law (minimum 20 hours)

- Training in interviewing techniques and testimony writing (10 hours)

- $\quad$ Training in ethical responsibilities (2 hours)

Training may consist of independent reading, observation of practitioners or other types of instruction.

A person who is recognized as meeting either of these criteria may offer the full services of a legal adviser to applicants in refugees.

\section{Annex 2}

COMPLAINT MECHANISM AS A FEATURE IN A PROFESSIONAL ACCOUNTABILITY STRUCTURE FOR LEGAL AID PROVIDERS

At the very least, every legal aid provider shall have a client complaint mechanism as part of its office handbook of oper- ating procedures. These procedures shall be communicated to each client at the beginning of the relationship.

Some suggested elements of the complaint procedure include:

1. Preprinted complaint forms which are in the major languages spoken by the client community. The form should assist the complainant in making the complaint by suggesting necessary elements such as date and place of action complained against and an opportunity to provide a narrative of the incident.

2. Each organization should determine the procedure for dealing with anonymous complaints. On their own anonymous complaints can never be the source of a negative action against an employee.

3. Instructions on how to communicate the complaint should appear on the form and also in a conspicuous public area of the legal aid provider's office.

4. The complaint should be investigated and resolved in a timely fashion by a disinterested party.

5. The results of the complaint process should be communicated to the complainant where known.

6. The employee complained against shall have the presumption of innocence.

7. The person complained against should be notified of the complaint. The person complained against should have a right to reply to the complaint and all evidence used against them and to be heard by the independent investigator.

8. The organization shall keep records of all complaints submitted as well as of the investigation findings and resolutions.

9. The range of sanctions for violations of ethical duties should be part of the office handbook of operating procedures.

\section{Notes}

1. James Hathaway, The Rights of Refugees under International Refugee Law (New York: Cambridge University Press, 2005) at 1; Lawyers Committee for Human Rights, African Exodus: Refugee Crisis, Human Rights and the 1969 OAU Convention (New York: Human Rights First, 1995, 2004); Guglielmo Verdirame and Barbara Harrell-Bond, Rights in Exile: Janus-Faced Humanitarianism (New York: Berghahn Books, 2005).

2. See US Committee for Refugees and Migrants, "Campaign to End Refugee Warehousing," online: <http://www.refugees.org/warehousing $>$.

3. Hathaway, supra note 1; Verdirame and Harrell-Bond, supra note 1.

4. I. Griek, "Access to Justice in Kenyan Refugee Camps Exploring the Scope of Protection," (M.Sc. thesis, School of 
Public Administration and Public Affairs, Leiden University, 2007); I. Griek, "Traditional Systems of Justice in Refugee Camps: Cause for Concern?" in D. Mukherjee, ed., Refugee Rights and Issues: Concepts and Country Experiences (Hyderabad, India: ICFAI University Press, 2007).

5. Hathaway, supra note 1 at 237.

6. I am aware of recent failed attempts for a refugee to travel on a CTD including to Germany, Kenya, Tanzania, and the US.

7. Exceptionally, "Kampala urban refugees access schools and health services, both the referral hospitals and health clinics run by the city council. The only issue is that they too must pay the usual fees just like hosts." Zachary Lomo, email to author, 1 August 2008.

8. Statute of the Office of the United Nations High Commissioner for Refugees, G.A. res. 428 (V), annex, 5 U.N. GAOR Supp. (No. 20) at 46, U.N. Doc. A/1775 (1950).

9. Ibid. at article 8 , para. (a).

10. Ibid. at article 8, para. (b).

11. UNHCR funds a group of "implementing partners" to deliver education and health services, and the World Food Programme (WFP) delivers food rations to refugees in camps. UNHCR is responsible for supplying micronutrients. This work, which had been largely conceived as "charity," has only recently begun to be conceived as part of a "rights-based" approach. A number of retraining courses have been offered to start altering the attitudes of UNHCR's NGO implementing partners. For example, in 2007 the American University in Cairo offered a two-week course in both English and Arabic on a rights-based approach to food supply in camps.

12. For example, Egypt-which has in the past tolerated refugees on its territory-is now regularly refouling recognized refugees as well as those seeking asylum. See Amnesty International, "Egypt: Amnesty International calls for President to stop flights to possible torture in Eritrea," Index Number: MDE 12/014/2008, 20 June 2008.

13. UNHCR, "States Parties to the 1951 Convention relating to the Status of Refugees and the 1967 Protocol," online: <http:// www.unhcr.org/protect/PROTECTION/3b73b0d63.pdf>.

14. K. Kamanga, "The (Tanzania) Refugees Act of 1998: Some Legal and Policy Implications” (2005) 18 J. of Refugee S. 100 at 116 .

15. It is understatement to say that the 1998 Tanzanian Act is outrageous in the extent of its non-compliance with the Refugee Convention. Kamanga's article (ibid.) is fairly muted in its analysis and critique. Again, as far as I know, no government official or parliamentarian in Tanzania has been approached about the need to reform this law.

16. See online: <http://www.refugeelawproject.org/resources/ legalres/refugeesact.pdf $>$.

17. See ibid., art. 4(d). Gender discriminating practices include "strict and forced adherence to a dress code, obligatory pre-arranged marriages, physically harmful facial or gen- ital mutilation, rape, domestic violence and other gender related negative activities."

18. Joao Pembele and six others v. Appeal Board for Refugee Affairs and five others (1996), Case No. 15931/96, Cape Prov. Div. [unreported].

19. J. Klaaren, "A Guide to South African Refugee Law," 16 May 1999, online: <http://www.law.wits.ac.za/school/klaaren/ sareflaw.htm>.

20. Most lawyers working in this field-including lawyers at UNHCR-have simply "learned on the job." At least in the UK and the Netherlands, the only two examples that I know of, lawyers who provide legal aid to refugees and who are paid under their government's schemes have to take regular courses to update themselves.

21. Law schools already recognize the student market for public interest work. Harvard Law School, for example, guarantees funding for any student who spends a summer working in the public interest. Last year, 373 students passed up lucrative associate positions at law firms to participate in the program. See online: <http://www.law.harvard.edu/students/sfs/sumfund $>$.

22. There several anti-apartheid NGOs transformed themselves to provide legal aid and policy advocacy for refugees.

23. See below for one exception in Hong Kong, although not normally regarded as "the South."

24. But see below for a record of the work of the Association of International Refugee Law Judges.

25. For example, the Danish government funded a huge project to upgrade the judicial system in Uganda, which went so far as to produce little handbooks to put in the pockets of police for easy reference. None of this program included even a reference to refugees although Uganda is a major host country.

26. See, online, for Uganda, <http://www.refugeelawproject. org>; for Kenya, <http://www.rckkenya.org>; for Egypt, $<$ http://www.amera-uk.org >; for Lebanon, <http://www. frontiersassociation.org $>$; and for Turkey, <http://www. hyd.org.tr/?sid=23>.

27. Mary Robinson, "Linkage between Human Rights and Refugees Issues," 1997, UNHCR, online: <http://www.unhchr. ch/huricane/huricane.nsf/view01/B6622AE1672268BBC125662E00352F7F>.

28. E. Ferris, "Protracted Refugee Situations, Human Rights and Civil Society" in G. Loescher et al., eds., Protracted Refugee Situations: Political, Human Rights and Security Implications (Tokyo: UN University, 2008) 85.

29. M. Kagan, "Frontier Justice: Legal Aid and UNHCR Refugee Status Determination in Egypt" (2006) 45 J. Refugee S. 19.

30. See online: $<$ http://www.rsdwatch.org $>$. All cases referred by UNHCR for resettlement are adjudicated by the government considering them. UNHCR's mandate status is not enough to get them automatically accepted. Since refugees usually have no idea what constitutes the grounds for asy- 
lum, they urgently need legal assistance for this process to be successful. Kagan, supra note 29.

31. See, for example, Iranian Refugee Alliance 1995, online: $<$ http://www.irainc.org/text/pub/report.html>; Michael Alexander, "Refugee Status Determination Conducted by UNHCR" (1999) 11 Int'l J. Refugee L. 251; M. Kagan, "Assessment of Refugee Status Determination Procedure at UNHCR's Cairo Office 2001-2002" (2002) [Working Paper No. 1, Forced Migration and Refugee Studies, American University in Cairo]. An extensive bibliography of such literature is shown online: <http://www.rsdwatch.org $>$.

32. Asylum Access, "Disclosure of evidence in UNHCR's refugee status determination procedures: Critique and recommendations for reform" (20 June 2008), online: <http:// www.rsdwatch.org/Disclosure\%20 of\%20Evidence\%20 in\%20UNHCR\%20RSD.pdf >. Such an illegal practice can be absolutely fatal to a case. For example, a refugee had been given a death sentence in absentia. Human Rights Watch (HRW) had written to UNHCR to alert them and recommend he be granted refugee status. The letter was misunderstood by UNHCR staff and his claim was rejected. Fortunately, but only by chance, his representative knew about the existence of this letter and wrote HRW to tell them how their evidence was being used. They immediately sent the legal advisor another copy so that there was evidence to reopen the case; eventually he was granted status.

33. On one occasion we were privy to the UNHCR's confidential Country of Origin Information (COI) on Sudan. It was completely inaccurate and out-of-date.

34. See online: <http://www.rsdwatch.org $>$. The RSD Unit at UNHCR Geneva has, as of 2007, conceded that appeals will be handled "where possible" by a senior member of staff who does not work in the RSD unit. This is as independent as appeals against UNHCR decisions will be in the foreseeable future. UNHCR has rejected the suggestion that an independent tribunal could be established in each country where UNHCR conducts RSD adjudications. The IARLJ has offered to train such tribunal members.

35. Although allowed by the protection officer in Cairo since legal aid became available there, some staff appeared to resent the presence of a legal advisor. And there was no guarantee that the interviewer read the dossier prepared for the claimant. AMERA has attempted to adapt to this latter problem by writing very brief submissions.

36. In Lebanon UNHCR has been conducting an "experiment" in its co-operation with the NGO, the Frontiers Ruwad Association.

37. See online: <http://www.rsdwatch.org $>$.

38. Barbara Harrell-Bond, "Starting a Movement of Refugee Legal Aid Organizations in the South” (2007) 19 J. Int'l Refugee L. 729-735; see also online: <http://www.rsdwatch. org/index_fi les/Page386.htm>.

39. Verdirame and Harrell-Bond, supra note 1.

40. Natalie Briant and Andrew Kennedy, "An Investigation of Perceived Needs and Priorities Held by African Refugees in an Urban Setting in a First Country of Asylum" (2004) 17 J. Refugee S. 437.

41. In Egypt, health services was the first priority need, legal aid second.

42. In 2008, the ICVA/UNHCR consultations took place in June.

43. Attending these meetings has been an important educational experience for the Southern NGOs. Some took advantage to also visit the offices of the UN Human Rights Commission. This office, which one would assume should be directly involved in violations of refugee rights, only acts on behalf of refugees in exceptional cases.

44. Since 2004, fairly dramatic improvements have been made in two country offices. Refugee legal aid NGOs in Turkey and Lebanon are now able to represent their clients. In Turkey they are sometimes able to see the transcripts, but in Lebanon a "feasibility" study is being carried out with Frontiers, the refugee legal aid NGO there, to give reasons for rejection and to allow access to claimants' file; see online $<$ http://www.rsdwatch.org $>$.

45. The justification for creating a code of professional ethics for NGOs conducting refugee legal aid arose because not all persons who work for them are lawyers, who would naturally be bound by the ethics of their own bar associations.

46. M. Kagan, "Is Truth in the Eye of the Beholder? Objective Credibility Assessment in Refugee Status Determination" (2003) 17 Geo. Immigr. L.J. 367 (cited by Singh v. Gonzalez, 403 F.3d. 1081 (9th Cir. 2005)).

47. Also discussed in Harrell-Bond, supra note 38. We appealed to a member of the International Refugee Law Judges (online: $<\mathrm{http}: / /$ www.iarlj.nl/general $>$ ) to ask them to intervene. He argued with the head of the RSD Unit in Geneva that this was not a UNHCR responsibility.

48. It was funded by the US Institute for Peace.

49. An NGO and a law firm from Hong Kong were included. Although China is a party to the Refugee Convention and Protocol, it has not been extended to the territory of Hong Kong, which receives refugees from the same war-torn countries as appear in most other host countries in the south. Guatemala was also represented.

50. M. Kenny, "The Nairobi Code: A client centred approach to ethical conduct" (2007) 35 Immigration Review 12; HarrellBond, supra note 38. See the Nairobi Code, AMERA UK, online: $<$ http://www.amera-uk.org/Files/Nairobi\%20Code1.pdf $>$.

51. Vision: SRLAN aims at transforming the disparate refugee rights organizations into a global movement to root refugee assistance in human rights and international law by increasing their co-operation, information sharing, and coordinated advocacy. Mission: a. Separately and in concert, our mission is to promote and advocate for the rights of refugees in places where they have previously been ignored. We address ourselves to any institution, government, intergovernment agency, or non-government organization that has the power to affect refugees' enjoyment of their human 
rights. b. We form this network in order to combine our efforts on issues of common concern, and to share as possible our resources. We work internally among ourselves to promote the highest standards of professional skill and ethics in our own work.

52. There is still too little recognition of the resources contained in UNHCR's RefWorld, not only among NGOs. At the 2007 Nairobi meeting, it was discovered that UNHCR's Kenyan Country Office's RSD officers were unaware of it although it has been doing RSD since 1991.

53. See online: <http://www.fahamu.org >.

54. For three years, running it has been voted one of the top ten websites that are changing the world of the internet and politics.

55. Examples include the independent Equinet (the Regional Network on Equity in Health in Southern Africa, online: $<$ http://www.equinetafrica.org >) and AU-Monitor, which was established by Fahamu to facilitate constructive engagement between African civil society organizations and the African Union.

56. In 2005 it won the Tech Museum Award for its contributions to distance learning for human rights.

57. In Egypt, for example, the Association for Human Rights Legal Aid (AHRLA), was closed by the government because it was prosecuting senior policemen for raping a refugee woman. It was successful-although the guilty party is freely living in his home despite his twenty-five-year sentence. AHRLA NGO was also representing a case against a member of the government security for the death of an Egyptian under torture.

58. Some in attendance at the meeting in Geneva recommended that even the list of member organizations should be password-protected in order that governments could not identify sources of information used by external lobbying groups such as Amnesty or HRW.

59. Each country office is responsible for producing an annual report that includes the protection problems refugees are facing. The sample from 1999 that I have read did not include information on demarches to governments or the response.

60. UNHCR, "Keeping the spirit of Cartagena alive, 20 years later," Colombia (11 November 2006), online: <http://www. unhcr.org/admin/ADMIN/4524bc952.pdf $>$.

61. MAWG is the Migration and Asylum Working Group of the Euro-Mediterranean Human Rights Network (EMHRN); online: <http://www.euromedrights.net>. It was set up in the frame of a project financed by the European Commission, under the AENEAS program, online:<http:// ec.europa.eu/europeaid/where/worldwide/migration-asylum/details_en.htm>.

62. See "UN human rights chief urges Egypt to stop deporting Eritrean asylum-seekers," UN News Centre (19 June 2008), online: <http://www.un.org/apps/news/story.asp?NewsID $=27078 \& \mathrm{Cr}=$ asylum $\& \mathrm{Cr} 1>$; "UNHCR alarmed by Egypt's forceful return of Eritrean asylum seekers," UN Radio (20
June 2008), online: <http://www.unmultimedia.org/radio/ english/detail/9935.html $>$.

63. We can assume that UNHCR was making démarches to the Egyptian government but this "quiet" diplomacy was largely ineffective.

64. Association for Human Rights Legal Aid (AHRLA) was closed by the Egyptian government following its defense in an open court of a refugee who had been raped by police and a person who died from torture by a member of the security. It is hard to believe that joining in a publicity campaign well underway would have similar consequences.

65. This represents the majority of SRLA Network members at the moment. Legal aid is provided in Ecuador, Egypt, Hong Kong, Kenya, Lebanon, Malta (not strictly part of the Global South as it is an EU country), Thailand, Turkey, Senegal, South Africa, and, on an ad hoc basis, in Zambia.

66. Verdirame and Harrell-Bond, supra note 1.

67. The American Anthropological Associations' Code of Ethics requires that any working relationship with affected individuals must be "beneficial to all parties involved." See <http://www.aaanet.org/committees/ethics/ethcode.htm>. See also Michael A. Rynkiewich and James P. Spradley, Ethics and Anthropology: Dilemmas of Fieldwork (New York: Wiley, 1976).

68. Jonathan A. Fox and L. David Brown, The Struggle for Accountability: The World Bank, NGOs and Grassroots Movements (Cambridge, Mass.: MIT Press, 1998).

69. See online: <http://www.iarlj.nl/general >.

70. Rosemary Byrne et al., eds., The Refugee Law Reader, 4th ed. (Dublin and Budapest: Hungarian Helsinki Committee, 2008), online: <http://www.refugeelawreader.org>.

71. Refugee Law Project, "Education and Training Department," Refugee Law Project online: $<$ http://www.refugeelawproject.org/about/edtr/index.htm $>$.

72. Geoffrey Care, email to author (15 July 2008); see also online: <http://www.iarlj.nl/general >.

73. AMERA Egypt, "History," AMERA Egypt online: <http:// www.amera-uk.org/egypt/history.html>.

74. AMERA UK, “Objectives \& History," AMERA UK online: $<$ http://www.amera-uk.org/objectives_history.html>.

75. See Stichting 3R, online: <http://www.stichting3R.nl>.

76. Both the 3 Rs Stifting and Asylum Access were begun by former interns who worked at AMERA Egypt and others. All three, including AMERA UK, are able to tap sources in their own countries that are only available through charities, foundations registered in those countries.

77. See WARIPNET, online: <http://www.waripnet.net>.

78. L. Weinberg, "West African Refugees and Internally Displaced Persons Network (WARIPNET) Senegal Legal Aid Assessment," on file with author. She has worked as an intern at AMERA Egypt for six months and at the Lutheran Immigrant and Refugee Services, Worcester, Massachusetts, and the Community Legal Services and Counselling Center, Cambridge, Massachusetts. 
79. See Helsinki Yurttaslar Dernegi, "An Evaluation of UNHCR Turkey's Compliance with UNHCR's RSD Procedural Standards" (September 2007), online: <http://www.hyd. org.tr $/$ ?pid $=553>$.

80. Personal Communication, Mr. Johnson Braham, who headed the Government's refugee office. Also in Uganda, a Senior Protection Office complained that the government's Refugee Eligibility Committee (REC) was being "too generous" in their decisions on RSD. Zachary Lomo, email message to author (1 August 2008).

81. James C. Hathaway, "Why Refugee Law Still Matters" (2007) 1 Melbourne J. of Int'l L. 3, online: <http://www.austlii.edu. au/au/journals/MelbJIL/2007/3.html $>$.

82. She was in Hong Kong handling family law cases, spearheading a campaign to build the first shelter for battered women, and lobbying successfully for legislation against domestic violence.

83. “Obituary," The Times of London (3 May 2002), online: $<$ http://pambakerfoundation.org/docs/Pam\%20Bakerobituary-Times.doc $>$.

84. Ibid.

85. Hoi Trinh now has worked tirelessly in the Philippines to find resettlement places with their families for the thousands of Vietnamese who were left behind in the 1990s when the US stopped taking refugees from there.

86. Secretary for Security v. Sakthevel Prabakar, CACV No. 211 of 2002.

87. States which have ratified the Convention Against Torture cannot send failed asylum seekers back to where they would face torture.

88. Mark Daly, email message to author (26 June 2007). According to UNHCR approximately 2,500 people register claims with them in Hong Kong each year. Over 90 per cent of asylum seekers claiming refugee status come from South and Southeast Asia; 10 per cent arrive from Africa. We are always looking for assistance from those with some relevant experience (paid or unpaid). We are looking for solicitors, trainees, and student interns committed to the area.
89. Adam Shapiro, a filmmaker, is also a co-founder of the International Solidarity Movement (ISM). The ISM is a Palestinian-led movement committed to resisting the Israeli occupation of Palestinian land using nonviolent, direct-action methods and principles. Founded by a small group of activists in August 2001, ISM aims to support and strengthen the Palestinian popular resistance by providing the Palestinian people with two resources: international protection and a voice with which to resist non-violently an overwhelming military occupation force. See online: $<$ http://www.palsolidarity.org/main/about-ism>.

Barbara Harrell-Bond, OBE, was the founder and director of the Refugee Studies Centre at the University of Oxford. Since retirement, she has held visiting positions at Makerere University and the Forced Migration and Refugee Studies Department of the American University in Cairo. She founded the Refugee Law Project, <http://www.refugeelawproject.org >, in 1999 in Uganda and the Africa and Middle East Refugee Assistance (AMERA), <http://www.amera-uk.org>, in 2000 in Cairo; both provide legal aid to refugees. Since 2007 she has been researching the situation of Iraqis in Cairo and supervising interns providing legal assistance for their resettlement claims. Some of her principal publications are: (with G. Verdirame), Rights in Exile: Janus-Faced Humanitarianism (New York: Berghahn Books, 2005); Imposing Aid: Emergency Assistance to Refugees (Oxford University Press, 1986); and (with D. Skinner and A. Howard) Community Leadership and the Transformation of Freetown (1801-1976) (The Hague: Mouton, 1977).

I want to thank all who commented on and added to this paper: Rachel Levian, Zachary Lomo, Alice Nah, John Quin, and Chris Szabla. I remain responsible for any errors. 